Volume 3, Number 1, 2017

\title{
Methods for Defining the Binary Coal Mixture Composition in the Pulverized Coal-Fired Boiler
}

\author{
Yevhen Pistun, Stepan Mysak*, Halyna Matiko \\ Lviv Polytechnic National University, 12 S. Bandery St., Lviv, 79013, Ukraine
}

Received: February 14, 2017. Revised: March 16, 2017. Accepted: March 22, 2017.

(c) 2017 The Authors. Published by Lviv Polytechnic National University.

\begin{abstract}
The paper deals with the methods for defining the composition of the coal mixture burnt in boilers at combined heat and power plants. Indirect methods for defining the proportions of the two grades of coal in the mixture based on the available information on the quality characteristics of the coal are proposed. According to the first method the coal mixture composition is determined based on the values of volatile substances content in the combustible mass of the coal mixture and of each grade of coal making up the mixture. The second method uses the lower combustion heat of the coal mixture and lower combustion heats of the two grades of coal that the mixture consists of. The uncertainties of the results obtained by the developed methods are evaluated.
\end{abstract}

Keywords: methods; coal mixture; mixture composition; boiler; pulverized coal system; uncertainty.

\section{Introduction}

Today Ukraine is facing the challenges of fuel supply to the thermal power plants (TPP) and its effective combustion. Sustainable operation of TPP is ensured by using different methods for fuel combustion optimization including those for non-standard fuel. One of the methods consists in obtaining a binary coal mixture by mixing different grades of coal possessing different characteristics. Thereat, it is important to control the proportions of the mixture components. Implementation of the direct measurement of the mixture composition is not provided for the existing technological processes, so such information is unavailable. Instead, a variety of methods for fuel quality characteristics defining and control are widely used, in particular coal sampling directly from the coal stream before the mill and carrying out the chemical analysis of the fuel [1-3]. It should be noted that the existing sampling methods are very time-consuming and labour-intensive. Besides, they output a common mean characteristic for a fuel mixture burnt in the boiler and there are no means for defining the coal mixture composition. Therefore it was proposed to develop methods for defining the proportions of the two grades of coal based on the results of the chemical analysis of the coal sampled directly from the coal stream before the mill.

\section{Goal and objectives}

The research aims at developing methods for defining the proportions of the two grades of coal in the pulverized coal system of the boiler which are based on the available information on the quality characteristics of the coal mixture and its components.

The above aim will be accomplished by fulfilling the following research objectives:

- analysis of the available literature in order to study the problem and its solutions;

- development of the methods for defining the binary coal mixture composition for the pulverized coal system of the boiler relying on the available quality data for the mixture and its components;

\footnotetext{
*Corresponding author. Email address: s.mysak750@gmail.com
}

This paper should be cited as: Y. Pistun, S. Mysak, H. Matiko. Methods for Defining the Binary Coal Mixture Composition in the Pulverized Coal-Fired Boiler. Energy Eng. Control Syst., 2017, Vol. 3, No. 1, pp. $1-8$. https://doi.org/10.23939/jeecs2017.01.001 
- evaluation the accuracy of the proposed methods;

- testing and implementation of the developed methods at TPP.

\section{Analysis of the known methods}

The conventional method of determining the proportions of the two grades of coal in the pulverized coal system of the boiler in which the mixture of these two coal grades is burnt consists in a continuous defining of the coal flow (usually, mass flow) for each coal grade fed into the pulverized coal system with the subsequent calculation of the amount of each coal grade fed into the system within a certain period of time and then defining the mixture composition $[2,3]$. The continuous weighing method can be used to measure the coal mass flow, and the computation can be done using an appropriate computing device.

In this method the coal mixture composition is determined using the equations [2]

$$
r_{1}=\frac{Q_{1}}{Q_{1}+Q_{2}} ; \quad r_{2}=\frac{Q_{2}}{Q_{1}+Q_{2}},
$$

where $r_{1}, r_{2}$ are the proportions of the first and second grades of coal in the mixture, respectively; $Q_{1}$ and $Q_{2}$ are the quantities of each grade of coal fed into the pulverized coal system within a certain period of time $t$ :

$$
Q_{1}=Q_{m 1} \cdot t, Q_{2}=Q_{m 2} \cdot t,
$$

where $Q_{m 1}$ and $Q_{m 2}$ are the mass flows of each grade of coal fed into the pulverized coal system.

The weak point of this approach is the inadequacy of the coal mass flow measurement method and lack of certified equipment for implementing this method with a pre-assigned accuracy.

At the same time there are methods for defining some coal mixture characteristics, for instance combustion heat, volatile substances contents in the combustible mass of mixture, humidity, temperature characteristics of the ash, milling characteristics, etc. [2]. Following the approved guidelines, coal samples are taken and analysed in the specialized laboratories. Methods for sampling and processing of the coal samples for chemical analysis are prescribed by the corresponding national standards and international regulations [4-7], which are mandatory in the heat power industry. They operate such terms as batch, primary sample and spot sample (or lot) whose definitions are provided below [2]:

"batch" means a quantity of fuel which is dispatched to the customer within a certain period of time and whose mean quality is characterized by one primary sample;

"primary sample" means a sample consisting of a necessary number of spot samples (lots) taken from the batch of fuel, which determines its mean quality;

"spot sample (lot)" means a quantity of fuel sampled from a certain spot by a single motion of the sampling device.

The preparatory stage consists in equipping the place of coal sampling with special sampling devices, inspection of the sampling place and cleaning of the coal residue and performance of respective calculations in order to assess the number of coal lots in the experiment. Since the quality of sampling determines the result of the chemical analysis, its planning should specify the selected sampling technique, number of samples, sampling accuracy, necessity to verify the accuracy by resampling, etc.

According to [4-6], sampling can be done from the coal stream in the places of its drop or from the moving coal stream (from the conveyer belt or coal feeder), as well as from the immobile layer in the railroad cars or coal bins. The highest sampling quality is ensured by coal sampling from the falling stream. Fuel sampling is usually done using mechanical methods or manually if there is no suitable conditions.

For the measurements to be representative, samples of particular lots of fuel should be taken depth-wise with samples taken from the top, middle and bottom layers and across the width of the stream. Usually, a short-time (2-3 s) diversion of the fuel stream into a special tray at the calculated intervals is used. Thereat, a mean technical 
characteristic of the fuel mixture is obtained. The total error of a sample's certain parameter evaluation (errors that occur at sampling, processing and analysis of samples are combined together) for the confidence level of $95 \%$ must not exceed the permissible base values specified for each parameter of the fuel [2].

According to the requirements imposed by the national and international standards [4-7], fuel samples must be taken in certain amounts at regular intervals. For instance, to do a general fuel analysis with the base accuracy, the number of raw coal lots is to be $n=32$, while for cleaned coal $n=16$. If the desired accuracy is different from the base one, the number of fuel lots $n_{1}$ to be taken is calculated using the equation:

$$
n_{1}=n \cdot A_{0}^{2}\left(5 A_{1}^{2}-A_{0}^{2}\right)
$$

where $n$ is the recommended number of lots for a certain grade of fuel which must be taken to make up a sample; $A_{0}$ is the base measurement accuracy, $A_{1}$ is the required measurement accuracy.

According to [2], the weight of each spot sample $m_{1}$ in kg taken as a primary sample cannot be lower than

$$
m_{1}=0.06 \cdot D
$$

where $m_{1}$ is the spot sample weight, $\mathrm{kg} ; D$ is the size of the maximum coal lump, mm, which is assumed to be equal to the size of the mesh catching no less than $5 \%$ wt of the coal.

The time interval $\tau$ between the lots sampled from the moving belt is calculated using the expression

$$
\tau=\frac{60 \cdot m}{G \cdot n}
$$

where $m$ is the weight of the fuel batch being studied, $t ; G$ is the productivity of the stream being studied, $t / h$;

For the fuel not to lose moisture, primary samples should be stored properly during the breaks between the sample preparation stages. Fuel samples should be kept in clean tight boxes lined with steel sheets or in steel jars with tight lids and stored in unheated premises. The sample storage duration before the analysis should not exceed 6 hours at temperatures not exceeding the sampling temperature.

The further sample preparation process, according to [8], includes sample crushing and separation into parts for the laboratory analysis. A properly taken and prepared sample is a prerequisite for the subsequent quality assessment of the fuel properties.

\section{New methods of defining the proportions of the two grades of coal in the pulverized coal system}

Taking into account that the method for defining the quality characteristics of the fuel fed into the drum mills of the pulverized coal system has been practically tested and standardized, our task was to use its results for calculating the composition of the coal mixture consisting of the two grades of coal which is fed into the drum mills of the pulverized coal system. Such methods for defining the coal mixture composition were proposed in $[8,9]$.

In the first method, the coal mixture composition is calculated on the basis of the known values of the volatile substances contents in the combustible mass of the coal mixture and those in the combustible mass of each grade of coal making in the mixture using the known equation [8]

$$
V_{C}=r_{1} \cdot V_{1}+\left(1-r_{1}\right) \cdot V_{2}
$$

where $V_{1}$ i $V_{2}$ are volatile substances contents in the combustible mass of each grade of coal in the mixture; $V_{C}$ is the volatile substances content in the combustible mass of the coal mixture.

Respectively, the proportion of the first grade of coal $r_{1}$ in the mixture is calculated as follows: 


$$
r_{1}=\frac{V_{C}-V_{2}}{V_{1}-V_{2}}
$$

and the proportion of the second grade of coal $r_{2}$ is equal to:

$$
r_{2}=1-r_{1}
$$

Let us define the probable uncertainty of the result of defining the proportions of the two grades of coal in the mixture fed into the drum mill of the pulverized coal system using the developed method.

According to [10] the combined standard uncertainty $u_{r_{1}}$ of the indirect measurements of the proportion of the first grade of coal $r_{1}$ is calculated using the formula

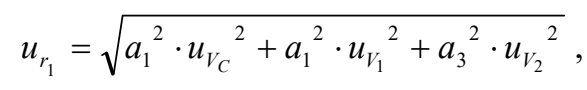

where $u_{V_{C}}$ is the standard uncertainty of the result of defining the volatile substances contents in the combustible mass of the coal mixture; $u_{V_{1}}$ is the standard uncertainty of the result of defining the volatile substances contents in the combustible mass of the first grade of coal; $u_{V_{2}}$ is the standard uncertainty of the result of defining the volatile substances contents in the combustible mass of the second grade of coal; $a_{i}$ are the corresponding weight factors which take into account the effect of each component of the relationship (8) on the result of the indirect measurement of the proportion $r_{1}$ of the first grade of coal: $a_{1}=\frac{\partial r_{1}}{\partial V_{C}}=\frac{1}{V_{1}-V_{2}} ; \quad a_{2}=\frac{\partial r_{1}}{\partial V_{1}}=\frac{V_{2}-V_{C}}{\left(V_{1}-V_{2}\right)^{2}}$; $a_{3}=\frac{\partial r_{1}}{\partial V_{2}}=\frac{V_{C}-V_{1}}{\left(V_{1}-V_{2}\right)^{2}}$.

If $u_{V_{C}}=u_{V_{1}}=u_{V_{2}}=u_{V}$ then the combined standard uncertainty of defining the proportion of the first grade of coal $r_{1}$ in the coal mixture is calculated using the formula

$$
u_{r_{1}}=\frac{u_{V}}{\left(V_{1}-V_{2}\right)^{2}} \sqrt{\left(V_{1}-V_{2}\right)^{2}+\left(V_{2}-V_{C}\right)^{2}+\left(V_{C}-V_{1}\right)^{2}} .
$$

The relative standard uncertainty of defining the proportion of the first grade of coal $r_{1}$ in the coal mixture is calculated using the expression [10]:

$$
u_{r_{1}}^{\prime}=\frac{u_{r_{1}}}{r_{1}} \cdot 100 \%=\frac{u_{V} \cdot 100 \%}{\left(V_{1}-V_{2}\right) \cdot\left(V_{c}-V_{1}\right)} \sqrt{\left(V_{1}-V_{2}\right)^{2}+\left(V_{2}-V_{C}\right)^{2}+\left(V_{C}-V_{1}\right)^{2}} .
$$

Using the TPP lab data, we studied the change of the coal mixture composition and its relative standard uncertainty $u_{r_{1}}^{\prime}$ depending on the value of the volatile substances content $V_{C}$ in the combustible mass of the coal mixture. Fig. 1 presents the change of the composition $\left(r_{1}\right)$ of the coal mixture consisting of non-baking coal (NBcoal) with $V_{1}=12 \%$ and anthracite (A-coal) with $V_{2}=3.5 \%$ versus the volatile substances content $V_{C}$ in the combustible mass of the coal mixture. 


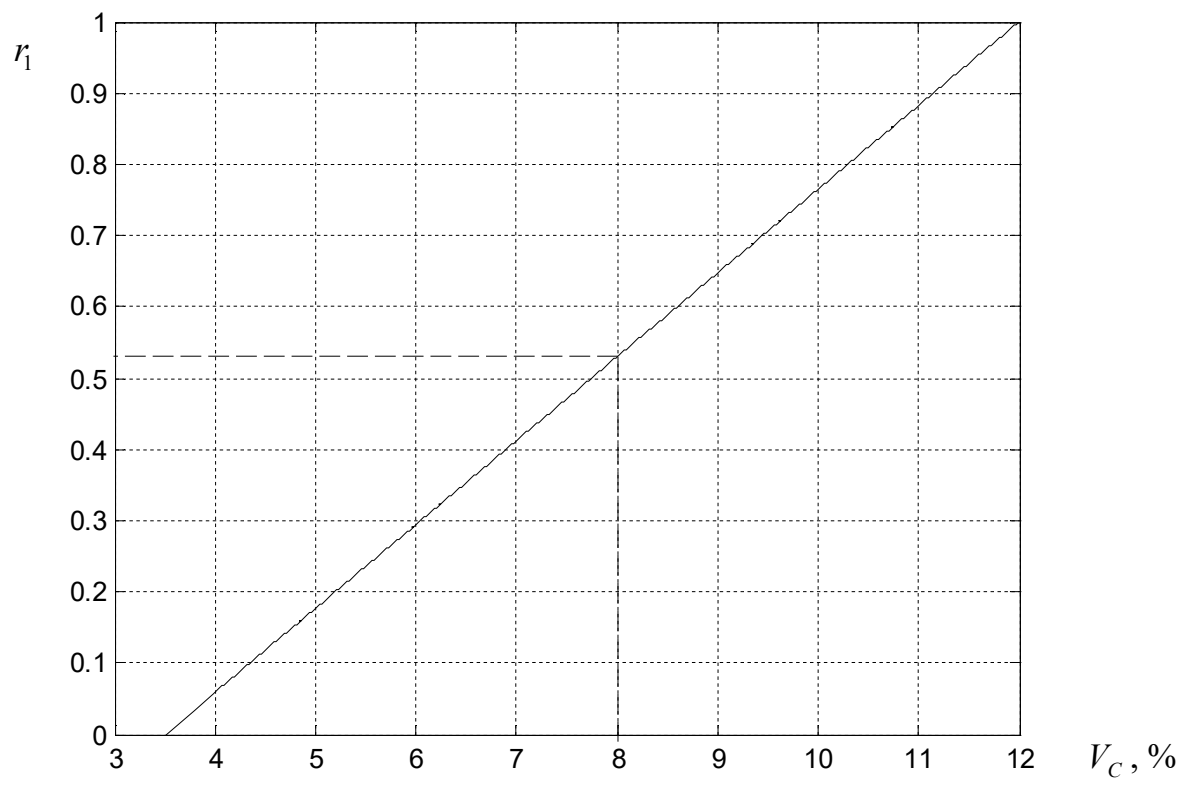

Fig.1. The NB-coal proportion $r_{1}$ in the coal mixture consisting of NB-coal and A-coal versus the volatile substances content $V_{C}$ in the combustible mass of the coal mixture

The value $V_{C}$ of the volatile substances content in the combustible mass of the coal mixture can vary from the volatile substances content $V_{2}$ in the combustible mass of the second grade of coal to the volatile substances content $V_{1}$ in the combustible mass of the first grade of coal. For instance, the volatile substances content $V_{C}=8 \%$ corresponds to the NB-coal proportion $r_{1}=0.53$ and the A-coal proportion $r_{2}=1-r_{1}=0.47$.

Fig. 2 shows the change of the relative standard uncertainty $u^{\prime}{ }_{r_{1}}$ of the result of defining the NB-coal proportion $r_{1}$ in the coal mixture depending on the value $V_{C}$ of the volatile substances content in the combustible mass of the coal mixture. For instance, the relative standard uncertainty $u_{r_{1}}$ of the NB-coal proportion $r_{1}$ in the coal mixture at $V_{C}=8 \%$ and $r_{1}=0.53$ is $u_{r_{1}}^{\prime}=5.4 \%$. As the A-coal proportion in the coal mixture increases the relative standard uncertainty of the mixture composition also increases, and at $V_{C} \rightarrow V_{1}$ the relative standard uncertainty $u_{r_{1}}^{\prime} \rightarrow \infty$.

The other method of defining the two-component coal mixture composition of the pulverized coal system consists in using the known equation which relates the coal mixture composition and the lower fuel mixture combustion heat and the lower combustion heat for each grade of coal [9]:

$$
Q_{H . c y M}=r_{1} \cdot Q_{H .1}+\left(1-r_{1}\right) \cdot Q_{H .2}
$$

where $Q_{n . c y s}$ is the lower combustion heat of coal mixture; $Q_{n .1}, Q_{\mu .2}$ are the lower combustion heats of the two grades of coal, respectively.

Hence, the proportion of the first grade of coal in the coal mixture is calculated as follows

$$
r_{1}=\frac{Q_{H . c y s}-Q_{H .2}}{Q_{u .1}-Q_{H .2}},
$$

and the proportion of the second grade of coal is equal to

$$
r_{2}=1-r_{1} .
$$




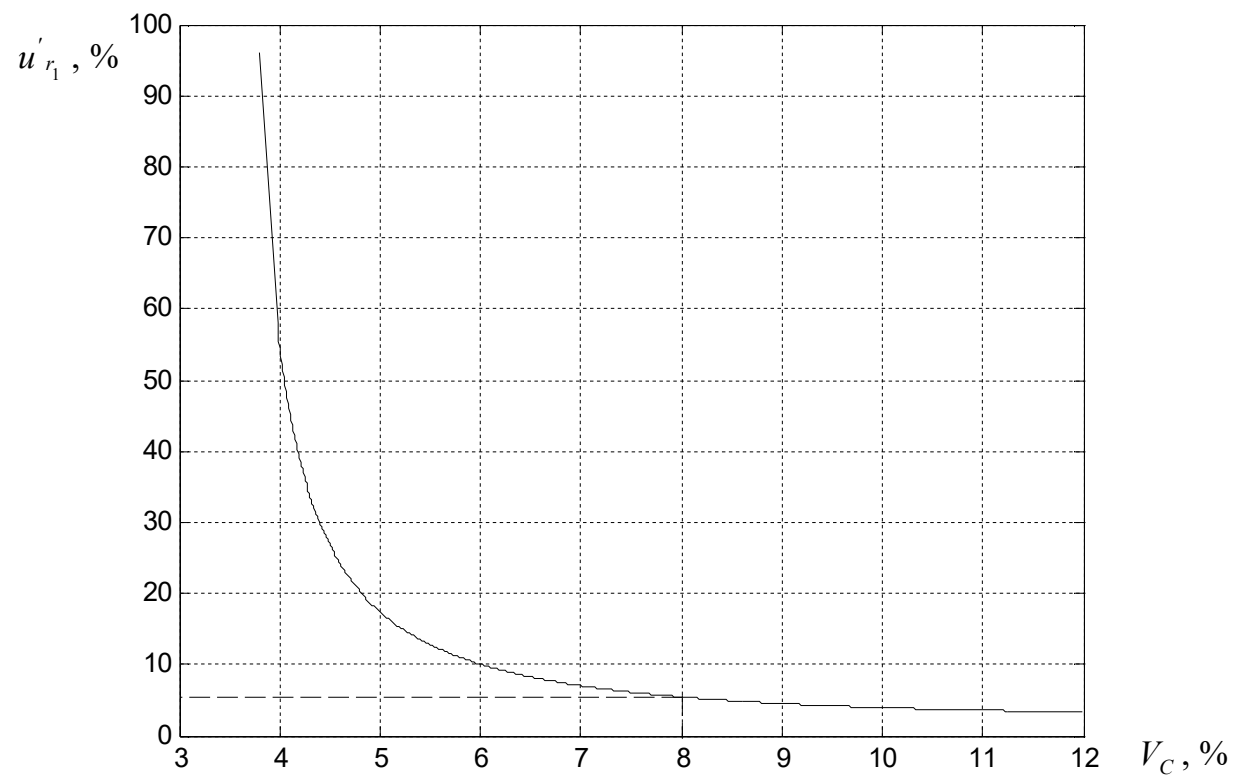

Fig. 2. The relative standard uncertainty $u_{r_{1}}^{\prime}$ of the NB-coal proportion in the coal mixture consisting of NB-coal and A-coal versus the volatile substances content $V_{C}$ in the combustible mass of the coal mixture

Taking into consideration that the relationship (12) for calculating the coal proportions in the mixture is similar to the equation (6), the equations (8-10) can be used for evaluating the probable uncertainty of defining the proportions of the two grades of coal in the coal mixture using the second method.

Therefore, the combined standard uncertainty $u_{r_{1}}$ of the indirect measurement results for the proportion $r_{1}$ of the first grade of coal by the second method is calculated using the formula

$$
u_{r_{1}}=\sqrt{a_{1}^{2} \cdot u_{Q_{u . c y u}}{ }^{2}+a_{1}^{2} \cdot u_{Q_{u .1}}{ }^{2}+a_{3}^{2} \cdot u_{Q_{u .2}}{ }^{2}},
$$

where $u_{Q_{\text {n...pn }}}$ is the standard uncertainty of the result of defining the lower combustion heat of coal mixture; $u_{Q_{u .1}}$, $u_{Q_{H, 2}}$ are the standard uncertainties of the results of defining the lower coal combustion heats for the two grades of coal, respectively; $a_{i}$ are the corresponding weight factors which take into account the effect of each component of the relationship (15) on the result of the indirect measurement of the proportion $r_{1}$ of the first grade of coal:

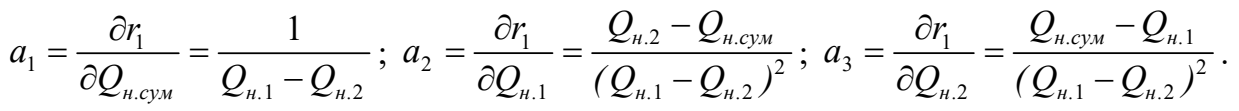

If $u_{Q_{n . c y n}}=u_{Q_{n .1}}=u_{Q_{u .2}}=u_{Q}$ then the combined standard uncertainty of defining the proportion $r_{1}$ of the first grade of coal in the coal mixture is calculated using the formula

$$
u_{r_{1}}=\frac{u_{Q}}{\left(Q_{u .1}-Q_{u .2}\right)^{2}} \sqrt{\left(Q_{u .1}-Q_{u .2}\right)^{2}+\left(Q_{u .2}-Q_{u . c y M}\right)^{2}+\left(Q_{u . c y M}-Q_{u .1}\right)^{2}} .
$$

The relative standard uncertainty of the result of defining the proportion $r_{1}$ of the first grade of coal in the coal mixture is defined as follows: 


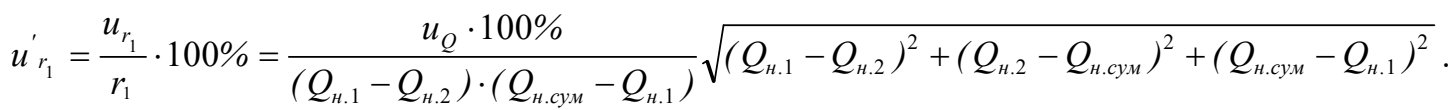

The resulting equations (10) and (16) for evaluating the uncertainty of the result of defining the proportions of the coal mixture components using the developed methods make it possible to forecast the accuracy of these methods' implementation for coal mixtures with various compositions.

The developed methods for calculating the proportions of the coal mixture components were implemented into the technological processes of non-standard fuel combustion at Burshtyn, Dobrotvir and Trypilska TPP.

\title{
Conclusions
}

1) The indirect methods for defining the binary coal mixture composition in the pulverized coal system of the boiler based on the available information on the quality characteristics of the coal have been proposed. According to the first method the composition of the coal mixture is defined by using the volatile substances contents in the combustible mass of each grade of coal in the coal mixture and the volatile substances content in the combustible mass of the coal mixture. In the second method the proportions of the two grades of coal are calculated based on the lower combustion heat of the coal mixture and the lower combustion heats of the two grades of coal.

2) The combined uncertainty of the result of defining the proportions of the two grades of coal using the developed methods was evaluated.

3) The proposed methods were tested and implemented into the technological processes of non-standard fuel combustion at Burshtyn, Dobrotvir and Trypilska TPP.

\section{References}

[1] Kapustianskyi, A. Study of the flame combustion of the non-baking coal and ash mixture. Scientific Bulletin of Ukrainian National Forestry University, No. 26.5, 2016, pp. 250-255. (in Ukrainian)

[2] Trembovlia, V., Fingel, E., Avdeieva, A. (1991) Heat performance testing of steam generating units. $2^{\text {nd }}$ Edition, Energoatomizdat Publishers, Moscow. (in Russian)

[3] Herasymenko, I., Herasymenko, A., Herasymenko, V. (1986) Reference manual on commissioning, maintenance and operation of steam generating units. Tekhnika Publishers, Kyiv. (in Russian)

[4] Hard coal, anthracite and coke. Mechanical sampling. Part 2. Coal. Sampling from moving streams. DSTU ISO 13909-2:2005 (ISO 139092:2001, IDT), 2005. (in Ukrainian)

[5] Hard coal, anthracite and coke. Mechanical sampling. Part 3. Coal. Sampling from immobile lots. DSTU ISO 13909-3:2005 (ISO 139093:2001, IDT), 2005. (in Ukrainian)

[6] Hard coal, anthracite and coke. Mechanical sampling. Part 4. Coal. Sample preparation for testing. DSTU ISO 13909-4:2005 (ISO 139094:2001, IDT), 2005. (in Ukrainian)

[7] Hard coal, anthracite and coke. Mechanical sampling. Part 7. Methods for estimating the precision of sampling, sample preparation and testing. DSTU ISO 13909-7:2006 (ISO 13909-7:2001, IDT), 2006. (in Ukrainian)

[8] Omelianovskyi, P., Holyshev, L., Mysak, Yo., Mysak, I. (2010) Method for defining the composition of the binary coal mixture of the pulverized coal-fired boiler. UA Patent No. 90343, Bul. No 8, F 23 K 1/00, G 01 N 25/00. (in Ukrainian)

[9] Mysak, S. (2014) Method for defining the composition of the binary coal mixture of the pulverized coal-fired boiler. UA Patent No. 104223, Bul. No 1, F 23K 1/00, G 01N 33/22 (2006.01), G 01 N 25/00. (in Ukrainian)

[10] Dorozhovets, M. (2007) Processing of measuring results. Tutorial, Lviv Polytechnic National University Publishing House, Lviv. (in Ukrainian)

\section{Методи визначення часток складових суміші двох марок вугілля пилосистеми котла}

\author{
Євген Пістун, Степан Мисак, Галина Матіко \\ Національний університет «Львівська політехніка», вул. С. Бандери, 12, м. Львів, 79013, Украӥна
}

\section{Анотація}

В статті розглянуто методи визначення часток складових вугільної суміші, що спалюється в паливні котла на теплових електричних станціях. Запропоновано непрямі методи визначення часток складових суміші 
двох марок вугілля, що базуються на наявній інформації щодо якісних характеристик вугілля. За першим методом склад вугільної суміші визначають за значеннями вмісту летких речовин на горючу масу вугільної суміші та кожної із марок вугілля, з яких складається суміш. У другому методі частку двох марок вугілля знаходять за нижчою теплотою згорання вугільної суміші та нижчою теплотою згорання вугілля двох марок, що входять до складу суміші. Виконана оцінка невизначеності результату визначення часток складових суміші двох марок вугілля пилосистеми котла за допомогою розроблених методів.

Ключові слова: методи; вугільна суміш; склад суміші; котел; пилосистема; невизначеність. 